\title{
Nitrogen fertilization effects on grain quality of durum wheat (Triticum turgidum L. var. durum) varieties in central Ethiopia
}

\author{
Leta Gerba $^{1^{*}}$, Belay Getachew ${ }^{2}$, Worku Walelign ${ }^{3}$ \\ ${ }^{1}$ The International Livestock Research Institute (ILRI), The International Water Management Institute (IWMI) in Addis Ababa, \\ Addis Ababa, Ethiopia; ${ }^{*}$ Corresponding Author: g.leta@cgiar.org \\ ${ }^{2}$ Common Market for Eastern and Southern Africa (COMESA), The Alliance for Commodity Trade in Eastern and Southern Africa \\ (ACTESA), Lusaka, Zambia; getab62@yahoo.com \\ ${ }^{3}$ Awassa College of Agriculture, University of Hawassa, Awassa, Ethiopia; walelignworku@yahoo.co.uk
}

Received 11 January 2013; revised 20 February 2013; accepted 28 February 2013

\section{ABSTRACT}

Four released durum wheat varieties, two medium tall (Arsi-Robe and Kilinto) and two recently released semi-dwarfs (Ude and Yerer) were evaluated under five different $N$ rates $(0,60,120$, 180 and $240 \mathrm{~kg} \cdot \mathrm{ha}^{-1}$ ) in 2005/06 growing season at Akaki and Debre Zeit, central Ethiopia. The quality responses of durum wheat varieties to different $\mathrm{N}$-fertilizer rates and the $\mathrm{N}$ responses between tall and short durum wheat varieties were assessed. Protein and gluten content, vitreous kernel count, thousand kernel weight, test weight and lodging were considered. Vitreous kernel count, protein and gluten content were higher at Debre Zeit than at Akaki. Unlike Debre Zeit, there were significant relationships between response variables and fertilizer levels at Akaki. Lodging slightly affected the medium tall varieties at Debre Zeit whereas it was not a problem at Akaki. At Akaki, varieties response to each additional $\mathrm{N}$ rate was entirely below the quality standard set by ICC, 2000 except for thousandkernel weight. Therefore, it is unwise to promote durum wheat scaling up/out program for quality production at Akaki.

Keywords: Gluten Content; N-Fertilization; Protein Content; Thousand Kernel Weight; Test Weight; Vitreous Kernel Count

\section{INTRODUCTION}

Durum wheat (Triticum turgidum L. var. durum) is the second most important wheat species grown in the world next to bread wheat (Triticum aestivum L.). It is the best wheat for pasta products due to its strong gluten, excel- lent amber color and superior cooking quality [1,2]. It has been cultivated in Ethiopia for thousands of years. However, it has been gradually replaced by bread wheat. Currently, the growing demand for pasta is enhancing durum wheat production. Low volumes and poor quality of the national wheat production compels Ethiopia pasta industries to import the required raw material [3]. As a result, the pasta factories annually import about 0.2 million tons of durum wheat.

The quality of durum wheat is highly dependent on the protein content of the grain, which is largely dependent on genotypes and influenced by environment, especially nitrogen $(\mathrm{N})$ availability of the soil [4]. Nitrogen fertilization management therefore offers the opportunity for increasing wheat protein content and other related quality traits. According to Motzo et al. (2004) grain protein content is a function of total nitrogen uptake and of the partitioning of nitrogen and dry matter to the grain [5]. Franzen and Goos (1997) also indicated that protein content consistently lower than $12 \%$ or starch content "yellow bean" kernels higher than $20 \%$ is an indication that a wheat producer needs to use more $\mathrm{N}$ fertilizer or better manage the $\mathrm{N}$ being applied [6].

In Ethiopia, durum wheat is mainly grown on heavy black clay soils (Vertisols) of highlands with altitude range of 1800 to $2800 \mathrm{~m}$ asl exclusively under rain fed conditions [7]. Vertisols in Ethiopia and other part of Africa generally have soil $\mathrm{pH}$ ranging between $7.5-8.5$ in the soil profile [8]. This high $\mathrm{pH}$ content of the Vertisols favors gaseous loss of ammonia when urea or ammonium fertilizers are applied to the surface $[9,10]$. As a result, durum wheat is mostly successful in soils with $\mathrm{pH}$ 6 in $\mathrm{CaCl}_{2}$ [11]. On the other hand, the low infiltration rates of vertisols could also create environment favorable for denitrification since $\mathrm{O}_{2}$ diffusion rate in water is very low $[12,13]$. Geleto et al. (1996) also reported that nitrogen deficiency is a common problem in cool, wet areas, 
such as in highland Vertisols [14]. Therefore, in addition to draining the soil, nitrogen fertilization of durum wheat is very important to mitigate the risk of $\mathrm{N}$ losses and to improve the quality of grain.

In the past, although Ethiopia is the largest producer in sub-Saharan Africa, little emphasis was given on improving the quality of durum wheat. Currently, the national research institutes and pasta processing industries are jointly working to improving durum wheat grain quality. Increasing domestic quality produce could mitigate not only the shortage but also substitutes the import of huge industrial raw materials. It also enables resource poor farmers fetch premium price. Therefore, it is vital to study soil fertility management practices across locations so as to improve the quality and market demand for the crop.

Bemnet et al. (2003) studied the effects of up to 120 $\mathrm{kg} \cdot \mathrm{N} \cdot \mathrm{ha}^{-1}$ on durum wheat quality using five medium-tall to tall varieties at Debre Zeit and Akaki [15]. Their results indicated that it is possible to grow quality durum wheat for the local industries at both locations, except vitreous kernel count (VKC) that was lower than the acceptable quality (80\%) at Akaki. Thus in areas like Akaki, a higher level of $\mathrm{N}$ has to be applied to produce quality seeds with high VKC [16]. On the other hand, higher levels of $\mathrm{N}$ may induce lodging on medium-tall varieties, in which case the possibility of growing semi-dwarf types were investigated.

The semi-dwarf durum wheat varieties, Ude and Yerer were released in 2002 and are currently under production. Both have high quality traits for pasta making and are relatively early maturing. The other two medium-tall varieties Arsi-Robe and Kilinto were respectively released in 1996 and 1994. Both are currently under production. Arsi-Robe is renowned for its higher protein content over Kilinto. However, Kilinto does grow well under wide ranges of rainfall (400 - $1200 \mathrm{~mm} / \mathrm{annum})$ [17]. Even though, they all have respective similarities with in their group, the semi-dwarf varieties have very close physical and quality attributes over the semi-tall varieties.

\section{Objectives}

1) To assess the quality responses of durum wheat varieties to different $\mathrm{N}$-fertilizer rates;

2) To compare the $\mathrm{N}$ responses between tall and short durum wheat varieties.

\section{MATERIALS AND METHODS}

\subsection{The Study Area}

The experiment was conducted at Debre Zeit research station and Akaki substation (Figure 1), in the 2005/06 main growing seasons. Debre Zeit Agricultural Research Center is located $50 \mathrm{~km}$ to the southeast of Addis Ababa $\left(8^{\circ} 44^{\prime} \mathrm{N}, 39^{\circ} 02^{\prime} \mathrm{E}\right)$ in mid-highland $(1900 \mathrm{~m}$ asl), and is characterized by $851 \mathrm{~mm}$ mean annual rainfall and mean temperature of about $18^{\circ} \mathrm{C}$ ([3]. Akaki substation is located $27 \mathrm{~km}$ to the south east of Addis Ababa $\left(08^{\circ} 54^{\prime} \mathrm{N}\right.$ $\left.38^{\circ} 45^{\prime} \mathrm{E}\right)$ in the highland area $(2200 \mathrm{~m}$ asl $)$ and is characterized by $1025 \mathrm{~mm}$ mean annual rainfall and about $17^{\circ} \mathrm{C}$ mean annual temperature (Figure 1). Mean monthly rainfall and temperature of the growing season for both sites is presented in Table 1. At both locations, pellic Vertisols are the major soil type.

\subsection{Treatments and Experimental Design}

Four released durum wheat varieties; two medium-tall (Arsi-Robe and Kilinto) and two recently released semidwarfs (Ude and Yerer), were evaluated under five Nitrogen $(\mathrm{N})$ rates $\left(0,60,120,180\right.$ and $\left.240 \mathrm{~kg} \cdot \mathrm{ha}^{-1}\right)$ with uniform basal application of $20 \mathrm{~kg} \cdot \mathrm{P} \cdot \mathrm{ha}^{-1}$. The treatments were factorially combined and arranged in a Randomized Complete Block Design (RCBD) with three replications (Table 2). The area of the experimental field is $737 \mathrm{~m}^{2}$. The plot size was $7.2 \mathrm{~m}^{2}$ and the space between each plot is $0.5 \mathrm{~m}$. Generally, 60 plots arranged in 3 blocks with 2 meter path between each block. Each plot had a total of six planting rows having $0.2 \mathrm{~m}$ intervals. Data were recorded from the four central rows of each plot. Seeding rate of $150 \mathrm{~kg} \cdot \mathrm{ha}^{-1}$ was used. Seeds were drilled by hand in the rows drawn using a manual row marker. Sowing dates were on 12 July 2005 for Akaki and on 21 July 2005 for Debre Zeit. Broad Bed and Furrows (BBF) was used to facilitate surface drainage of the Vertisols [18]. Split application of $\mathrm{N}$ fertilizer at sowing $(50 \%$, except the control) and the remaining at the end of tillering has been done to reduce the risk of loss by applying a single, high nitrogen early in the season ([19,20]. Post-emergence weed control was by hand weeding. Harvesting dates were 19-20 November for Debre Zeit and 24-25 November for Akaki.

\subsection{Data Collection and Analysis}

Composite topsoil samples $(0-30 \mathrm{~cm})$ from both locations were randomly taken from representative areas using augur. The percent organic matter and organic carbon of the sampled soils was determined using the wet oxidation method [21,22]. Total nitrogen $(\mathrm{N})$ was determined by the Kjeldhal method [23-25]. Available phosphorus (P) was determined by the Olsen method [26]. Soil $\mathrm{pH}$ was measured potentiometrically in the supernatant suspension of a 1:1 liquid mixture using $\mathrm{pH}$ meter in water $\left(\mathrm{pH}-\mathrm{H}_{2} \mathrm{O}\right)$ [27]. Lodging was recorded according to lodging index [28]. About $250 \mathrm{~g}$ seed samples from 120 plots each over two locations were taken after threshing for analysis. Each sample was ground, sieved and analyzed for total nitrogen content. Whole mill nitrogen $(\mathrm{N})$ contents were determined using macro Kjel- 


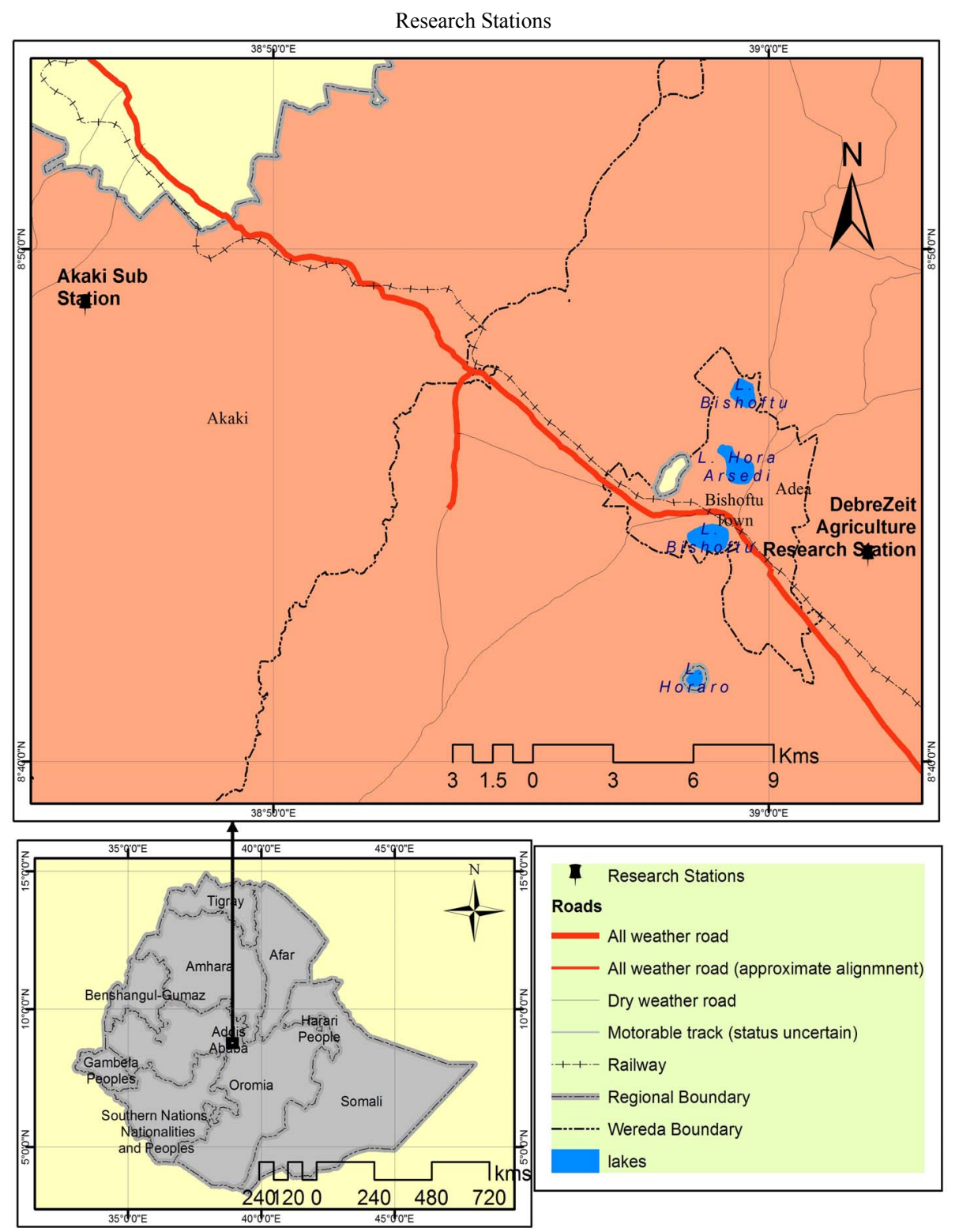

Figure 1. Location of the study sites (Debre Zeit and Akaki).

Table 1. Mean rainfall $(\mathrm{mm})$ and temperature $\left({ }^{\circ} \mathrm{C}\right)$ of Debre Zeit and Akaki during the growing season.

\begin{tabular}{cccccccccccc}
\hline \multirow{2}{*}{ Location } & Year & \multicolumn{4}{c}{ Monthly rainfall (mm) } & \multicolumn{5}{c}{ Temperature ( $\left.{ }^{\circ} \mathbf{C}\right)$} \\
\cline { 3 - 11 } & & June & July & August & September & $\Sigma$ & June & July & August & September \\
\hline \multirow{2}{*}{ Akaki } & Previous year & 122.2 & 232.5 & 211.9 & 92.1 & 658.7 & 20.7 & 19.4 & 19.5 & 20.0 \\
& $2005 / 6$ & 139.9 & 234.8 & 231.0 & 149.7 & 755.4 & 20.9 & 19.5 & 20.1 & 20.3 \\
& Previous year & 98.9 & 234.6 & 213.1 & 72.3 & 618.9 & 20.0 & 19.0 & 18.8 & 18.5 \\
\multirow{2}{*}{ D/Zeit } & $2005 / 6$ & 103.3 & 179.9 & 138.2 & 129.3 & 550.7 & 19.1 & 18.4 & 18.9 & 18.6 \\
\hline
\end{tabular}

dahl-method. The analysis was made in the Soil and Water Research Laboratory at Debre Zeit Agricultural Research Center (DZARC).
Gluten content was determined at Kality Food Share Company by taking $10 \mathrm{gm}$ of endosperm flour and the dough was prepared from the flour and $5 \mathrm{ml}$ of $2 \%$ So- 
Table 2. Arrangements of experimental treatments.

\begin{tabular}{ccccccccccccccccccccccc}
\hline \multirow{2}{*}{$\mathrm{B}_{1}$} & $\mathrm{~V}_{1}$ & $\mathrm{~V}_{3}$ & $\mathrm{~V}_{1}$ & $\mathrm{~V}_{3}$ & $\mathrm{~V}_{2}$ & $\mathrm{~V}_{2}$ & $\mathrm{~V}_{4}$ & $\mathrm{~V}_{1}$ & $\mathrm{~V}_{2}$ & $\mathrm{~V}_{2}$ & $\mathrm{~V}_{2}$ & $\mathrm{~V}_{4}$ & $\mathrm{~V}_{4}$ & $\mathrm{~V}_{3}$ & $\mathrm{~V}_{1}$ & $\mathrm{~V}_{3}$ & $\mathrm{~V}_{4}$ & $\mathrm{~V}_{4}$ & $\mathrm{~V}_{1}$ & $\mathrm{~V}_{3}$ \\
& $\mathrm{~F}_{5}$ & $\mathrm{~F}_{5}$ & $\mathrm{~F}_{1}$ & $\mathrm{~F}_{4}$ & $\mathrm{~F}_{3}$ & $\mathrm{~F}_{4}$ & $\mathrm{~F}_{4}$ & $\mathrm{~F}_{4}$ & $\mathrm{~F}_{2}$ & $\mathrm{~F}_{1}$ & $\mathrm{~F}_{5}$ & $\mathrm{~F}_{5}$ & $\mathrm{~F}_{3}$ & $\mathrm{~F}_{1}$ & $\mathrm{~F}_{3}$ & $\mathrm{~F}_{2}$ & $\mathrm{~F}_{1}$ & $\mathrm{~F}_{2}$ & $\mathrm{~F}_{2}$ & $\mathrm{~F}_{3}$ \\
& $\mathrm{~V}_{3}$ & $\mathrm{~V}_{3}$ & $\mathrm{~V}_{3}$ & $\mathrm{~V}_{2}$ & $\mathrm{~V}_{2}$ & $\mathrm{~V}_{3}$ & $\mathrm{~V}_{4}$ & $\mathrm{~V}_{3}$ & $\mathrm{~V}_{4}$ & $\mathrm{~V}_{2}$ & $\mathrm{~V}_{1}$ & $\mathrm{~V}_{4}$ & $\mathrm{~V}_{1}$ & $\mathrm{~V}_{1}$ & $\mathrm{~V}_{1}$ & $\mathrm{~V}_{4}$ & $\mathrm{~V}_{1}$ & $\mathrm{~V}_{4}$ & $\mathrm{~V}_{2}$ & $\mathrm{~V}_{2}$ \\
& $\mathrm{~F}_{2}$ & $\mathrm{~F}_{4}$ & $\mathrm{~F}_{3}$ & $\mathrm{~F}_{3}$ & $\mathrm{~F}_{2}$ & $\mathrm{~F}_{1}$ & $\mathrm{~F}_{3}$ & $\mathrm{~F}_{5}$ & $\mathrm{~F}_{2}$ & $\mathrm{~F}_{4}$ & $\mathrm{~F}_{1}$ & $\mathrm{~F}_{1}$ & $\mathrm{~F}_{2}$ & $\mathrm{~F}_{4}$ & $\mathrm{~F}_{5}$ & $\mathrm{~F}_{4}$ & $\mathrm{~F}_{3}$ & $\mathrm{~F}_{5}$ & $\mathrm{~F}_{5}$ & $\mathrm{~F}_{1}$ \\
& $\mathrm{~V}_{2}$ & $\mathrm{~V}_{4}$ & $\mathrm{~V}_{4}$ & $\mathrm{~V}_{4}$ & $\mathrm{~V}_{4}$ & $\mathrm{~V}_{1}$ & $\mathrm{~V}_{1}$ & $\mathrm{~V}_{2}$ & $\mathrm{~V}_{2}$ & $\mathrm{~V}_{4}$ & $\mathrm{~V}_{2}$ & $\mathrm{~V}_{1}$ & $\mathrm{~V}_{3}$ & $\mathrm{~V}_{1}$ & $\mathrm{~V}_{2}$ & $\mathrm{~V}_{3}$ & $\mathrm{~V}_{3}$ & $\mathrm{~V}_{1}$ & $\mathrm{~V}_{3}$ & $\mathrm{~V}_{1}$ \\
& $\mathrm{~F}_{1}$ & $\mathrm{~F}_{4}$ & $\mathrm{~F}_{2}$ & $\mathrm{~F}_{3}$ & $\mathrm{~F}_{5}$ & $\mathrm{~F}_{3}$ & $\mathrm{~F}_{4}$ & $\mathrm{~F}_{4}$ & $\mathrm{~F}_{2}$ & $\mathrm{~F}_{1}$ & $\mathrm{~F}_{3}$ & $\mathrm{~F}_{1}$ & $\mathrm{~F}_{2}$ & $\mathrm{~F}_{5}$ & $\mathrm{~F}_{5}$ & $\mathrm{~F}_{1}$ & $\mathrm{~F}_{3}$ & $\mathrm{~F}_{2}$ & $\mathrm{~F}_{5}$ & $\mathrm{~F}_{4}$ \\
\hline
\end{tabular}

$\mathrm{B}_{1}=$ block $1, \mathrm{~B}_{2}=$ block $2, \mathrm{~B}_{3}=$ block $3 ; \mathrm{V}_{1}=$ Arsi-Robe, $\mathrm{V}_{2}=$ Kilinto, $\mathrm{V}_{3}=$ Ude, $\mathrm{V}_{4}=$ Yerer; $\mathrm{F}_{1}=$ Zero fertilizer, $\mathrm{F}_{2}=60 \mathrm{~kg} \cdot \mathrm{N}, \mathrm{F}_{3}=120 \mathrm{~kg} \cdot \mathrm{N}, \mathrm{F}_{4}=180 \mathrm{~kg} \cdot \mathrm{N}$, $\mathrm{F}_{5}=240 \mathrm{~kg} \cdot \mathrm{N}$.

dium Chloride solutions. The dough ball was made for eight minutes [29] and then by washing away the starch using the sodium chloride solution, the wet gluten was isolated from the starch and other soluble materials. The washed away dough was frequently pressed in the middle of dough presser to reduce the moisture content of the dough ball. Ultimately, converted percentage weight of the wet gluten was recorded.

Eventually, grain protein, vitreous kernels count, test weight, thousand-kernel weight and wet gluten data were collected. The data was subjected to Analysis of Variance using SAS statistical software [30]. A regression analysis to examine the relationship between dependent variables and the independent variable was done.

\section{RESULTS AND DISCUSSION}

Due to heterogeneity of data over location, combined analysis of protein content was not done. Quality response of durum wheat varieties at two locations were independently evaluated for their industrial quality. At Debre Zeit, grain analysis gave slightly higher protein content than Akaki (Table 3). This could be attributed to the higher nitrogen in the soil left over from the previous season (Table 4) and the warmer weather condition at Debre Zeit. In contrast to the findings of Ames et al. (2003) and Metho et al. (1997) additional nitrogen fertilization did not significantly increase grain protein content of the varieties at both locations (Table 3) [31, 32].

ANOVA at Debre Zeit showed that there were no significant differences in protein content among $\mathrm{N}$ rates and fertilizer $\mathrm{x}$ varieties interaction, but there was significant $(\mathrm{P}<0.05)$ difference among varieties (Table 5). The two semi dwarf varieties Ude and Yerer gave high protein yield, comparing to the other two medium tall varieties (Table 6). Contrary to the findings of Bemnet et al. (2003), Arsi-Robe had the lowest protein content that could be attributed to lodging of the variety right after heading.

At Akaki, the effect of $\mathrm{N}$ rates on protein content was not significant $(\mathrm{P}<0.05)$. There was also no significant difference among varieties, and varieties $\mathrm{x}$ fertilizer interaction (Table 5). This study agrees to Bemnet et al. (2003) at Akaki. The relatively lower but acceptable grain protein content may be partially attributed to the high rainfall that might have resulted in $\mathrm{N}$ loss notably through gaseous/denitrification, leaching, and lower temperature of the area. Abaye et al. (1997) reported that drier and/or warmer condition during the growing season enhances the accumulation of higher grain protein. According to Simmonds (1989) starch production is favored rather than protein under high rainfall and low soil fertility conditions [33]. This could also lead to dilution, and hence low protein content.

Bemnet et al. (2003) and Campbell et al. (1993) reported that most grain quality traits in wheat, including protein content are affected by genetic and environmental factors. During crop maturity period, however, chilly and windy weather prevailed at both locations with condition at Akaki being chiller than that of Debre Zeit. According to Srivastava (1984), durum wheat is susceptible to low temperature and severe frost [34].

At Debre Zeit, all varieties gave substantial proportion of vitreous kernel counts. There was no significant $(\mathrm{P}<$ $0.05)$ difference among varieties, fertilizer, and varieties $\times$ fertilizer interaction (Table 5). The highest mean vitreous kernel count $(99.2 \%)$ showed that at Debre Zeit it is possible to produce high quality durum wheat. Similar kernel vitreousness among all varieties at Debre Zeit might be attributed to the relatively low rainfall, warmer condition and the carry over (residual) effects of nutrient in the soil (Tables 1 and 4). Bemnet et al. (2003) also reported that Debre Zeit has favorable condition for kernel vitreousness.

At Akaki kernel vitreousness was very poor compared to equal $\mathrm{N}$ rate at Debre Zeit (Table 3 ). Mean vitreous kernel count at Akaki was extremely below the standard in which case variety Kilinto was remarkably inferior to all other varieties (Table 6). The high rainfall that prevailed during the growing season might have attributed to lower vitreousness. According to Simmonds (1989), starch production is favored rather than vitreous kernel count under high rainfall and lower soil fertility conditions. In general, kernel vitreousness response of varieties to $\mathrm{N}$ rates at Akaki was very poor except for varieties Arsi-Robe and Yerer at 180 and $240 \mathrm{~kg} \cdot \mathrm{N} \cdot \mathrm{ha}^{-1}$, respectively.

Wet gluten was determined according to ICC, 2000. At 
Table 3. Effect of $\mathrm{N}$ rates on mean values of quality traits of durum wheat varieties grown at Debre Zeit and Akaki in 2005.

\begin{tabular}{cccccccccccc}
\hline \multicolumn{9}{c}{ Debre Zeit } \\
\hline N rates $\left({\left.\mathrm{kg} \cdot \mathrm{ha}^{-1}\right)}^{\text {GP }(\%)}\right.$ & VKC $(\%)$ & WG $(\%)$ & TKW $(\mathrm{g})$ & $\mathrm{TW}\left(\mathrm{kg} \cdot \mathrm{hl}^{-1}\right)$ & GP $(\%)$ & VKC $(\%)$ & WG $(\%)$ & $\mathrm{TKW}(\mathrm{g})$ & $\left.\mathrm{TW}(\mathrm{kg} \cdot \mathrm{hl})^{-1}\right)$ \\
\hline 0 & 14.9 & 97.3 & 41.0 & 33.2 & 75.9 & 14.3 & 43.3 & 24.9 & 36.1 & 78.2 \\
60 & 15.9 & 99.2 & 49.9 & 31.0 & 75.2 & 12.1 & 21.8 & 23.0 & 39.3 & 77.7 \\
120 & 16.6 & 99.8 & 51.4 & 29.4 & 73.7 & 13.1 & 50.4 & 27.0 & 41.1 & 79.0 \\
180 & 16.0 & 99.8 & 53.3 & 29.3 & 73.7 & 13.1 & 71.5 & 32.5 & 44.3 & 79.0 \\
240 & 16.2 & 99.9 & 54.5 & 29.4 & 73.8 & 14.9 & 75.7 & 34.0 & 46.0 & 78.0 \\
Mean & 15.9 & 99.2 & 50.0 & 30.4 & 74.5 & 13.5 & 52.6 & 28.3 & 41.3 & 78.4 \\
LSD (0.05) & NS & NS & 3.9 & 1.1 & 0.9 & NS & 9.7 & 2.2 & 1.70 & NS \\
\hline
\end{tabular}

$\mathrm{GP}=$ grain protein; $\mathrm{VKC}=$ vitreous kernel count; $\mathrm{WG}=$ wet gluten; $\mathrm{TKW}=$ thousand kernel weight; $\mathrm{TW}\left(\mathrm{kg} \cdot \mathrm{hl}^{-1}\right)=$ test weight $\mathrm{kg} / \mathrm{hectoliter}$; $\mathrm{NS}=$ not significant.

Table 4. Pre-treatment soil characteristics of the study area.

\begin{tabular}{ccccccccc}
\hline \multirow{2}{*}{ Location } & Year & \multicolumn{9}{c}{ Soil characteristics } \\
\cline { 3 - 8 } & & $\mathrm{pH}$ & $\mathrm{OM}(\%)$ & OC (\%) & $\mathrm{N}(\%)$ & $\mathrm{C} / \mathrm{N}$ & $\mathrm{P}(\mathrm{ppm})$ \\
\hline D/Zeit & $2005 / 6$ & 6.47 & 1.02 & 0.59 & 0.170 & 3.5 & 22.6 \\
Akaki & $2005 / 6$ & 6.37 & 0.76 & 0.44 & 0.045 & 9.8 & 4.9 \\
\hline
\end{tabular}

$\mathrm{pH}=$ measure of acidity/alkalinity; $\mathrm{OM}=$ organic matter; $\mathrm{OC}=$ organic carbon; $\mathrm{N}=$ available nitrogen; $\mathrm{P}=$ available phosphorus.

Table 5. Mean square of quality traits of durum wheat varieties grown at Debre Zeit and Akaki in 2005.

\begin{tabular}{cccccccccccc}
\hline \multicolumn{9}{c}{ Debre Zeit } \\
\hline Sources & DF & GP (\%) & VKC (\%) & WG (\%) & TKW (g) & TW $\left(\mathrm{kg} \cdot \mathrm{hl}^{-1}\right)$ & GP (\%) & VKC (\%) & WG (\%) & TKW $(\mathrm{g})$ & TW $\left(\mathrm{kg} \cdot \mathrm{hl}^{-1}\right)$ \\
\hline Replication & 2 & 2.6 & 12.1 & 125.9 & 2.1 & 1.2 & 8.3 & 38.8 & 9.1 & 61.2 & 14.0 \\
Variety (V) & 3 & $12.8^{*}$ & 9.4 & $379.7^{* *}$ & $97.9^{* *}$ & $43.0^{* *}$ & 6.1 & $4434.0^{* *}$ & $291.0^{* *}$ & $119.9^{* *}$ & $10.7^{* *}$ \\
Fertilizer (F) & 4 & 4.3 & 14.4 & $343.2^{* *}$ & $33.5^{* *}$ & $12.1^{* *}$ & 14.9 & $5779.5^{* *}$ & $272.0^{* *}$ & $182.6^{* *}$ & 3.3 \\
V $\times$ F & 12 & 3.3 & 3.1 & 38.8 & 2.1 & 1.4 & 3.8 & $440.0^{* *}$ & $20.8^{* *}$ & $19.8^{* *}$ & 3.3 \\
Error & 38 & 3.5 & 6.0 & 22.6 & 1.7 & 0.9 & 6.5 & 137.3 & 7.2 & 4.0 & 2.0 \\
C.V. (\%) & & 2.5 & 11.7 & 9.5 & 1.3 & 4.2 & 22.0 & 18.9 & 9.5 & 1.8 & 4.9 \\
\hline
\end{tabular}

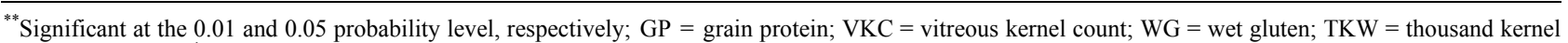
weight; $\mathrm{TW}\left(\mathrm{kg} \cdot \mathrm{hl}^{-1}\right)=$ test weight $\mathrm{kg} /$ hectoliter.

Table 6. Mean values of quality traits of durum wheat varieties grown at Debre Zeit and Akaki in 2005.

\begin{tabular}{ccccccccccc}
\hline \multicolumn{1}{c}{ Debre Zeit } \\
\hline Variety & GP (\%) & VKC (\%) & WG (\%) & TKW (g) & TW $\left({\left.\mathrm{kg} \cdot h l^{-1}\right)}^{\text {GP }(\%)}\right.$ & VKC (\%) & WG $(\%)$ & TKW $(\mathrm{g})$ & TW $\left(\mathrm{kg} \cdot \mathrm{hl}^{-1}\right)$ \\
\hline Arsi-Robe & 14.9 & 99.3 & 51.0 & 33.0 & 76.7 & 13.5 & 62.5 & 32.5 & 37.2 & 78.2 \\
Kilinto & 15.3 & 98.1 & 44.8 & 32.1 & 75.0 & 13.2 & 27.1 & 22.3 & 43.6 & 79.0 \\
Ude & 16.8 & 99.7 & 47.8 & 29.2 & 73.1 & 14.4 & 57.3 & 28.0 & 42.3 & 77.4 \\
Yerer & 16.6 & 99.8 & 56.6 & 27.5 & 73.2 & 12.9 & 63.3 & 30.3 & 42.2 & 79.2 \\
Mean & 15.9 & 99.2 & 50.0 & 30.4 & 74.5 & 13.5 & 52.6 & 28.3 & 41.3 & 78.4 \\
LSD (0.05) & 1.4 & NS & 3.5 & 0.95 & 0.7 & NS & 8.7 & 2.0 & 1.5 & 1.0 \\
\hline
\end{tabular}

$\mathrm{GP}=$ grain protein; $\mathrm{VKC}=$ vitreous kernel count; $\mathrm{WG}=$ wet gluten; $\mathrm{TKW}=$ thousand kernel weight; $\mathrm{TW}=$ test weight; $\mathrm{NS}=$ not significant. 
Debre Zeit, extremely high gluten content, $54.5 \%$ was recorded at $240 \mathrm{~kg} \cdot \mathrm{N} \cdot \mathrm{ha}^{-1}$ (Table 3). It is higher than any of the imported hard/or durum wheat ever recorded in Ethiopia. Hence, gluten content at all $\mathrm{N}$ rates was enormous compared to any of the domestic produce. It increased with increasing $\mathrm{N}$ rates. Although all varieties at all $\mathrm{N}$ rates gave acceptable wet gluten content, Yerer's result was superior to other varieties (Table 6). High mean gluten content of durum wheat varieties at Debre Zeit corroborates the suitability of the location for growing durum wheat with excellent cooking quality.

At Akaki, there were significant differences due to the main effects and the interaction for gluten content. Regardless of protein content, varietal difference was observed for all estimates of gluten strength. Gluten content increased with increasing $\mathrm{N}$ rates, generally. However, only the product from Arsi-Robe and Yerer met the domestic quality standards (Table 6). At both locations, the gluten content of Kilinto was inferior to all other varieties (Table 6).

At Debre Zeit, as shown in Table 3 there was a decrease in thousand-kernel weight with increasing $\mathrm{N}$ rate. There were significant differences among varieties and $\mathrm{N}$ rates. Thousand kernel weight has shown a linear relationship with $\mathrm{N}$ rates at both locations but with opposite trends (Figure 2). Hadjichristoudoulou (1979) reported that there was no effect of $\mathrm{N}$ rate on thousand kernel weight. Campbell et al. (1977) reported that $\mathrm{N}$ rate decreased thousand kernel weights or had no effect [35]. The control treatment at Debre Zeit gave a relatively higher thousand-kernel weight, but the mean thousandkernel weight ( $30.4 \mathrm{~g}$ ) was the minimum compared to the standard. In addition to increased soil $\mathrm{N}$ rates, it may also be attributed to the prevailed cold and windy weather condition during the grain filling period.

At Akaki, mean thousand-kernel weight (41.3 g) showed positive response to $\mathrm{N}$ rates. Both the main effects and the interactions were significant. It had significant linear relationship to $\mathrm{N}$ rate (Figure 2). At 180 and 240 $\mathrm{kg} \cdot \mathrm{N} \cdot \mathrm{ha}^{-1}$ higher thousand kernel weights of 44 and $46 \mathrm{~g}$, respectively, were recorded (Figure 2, Table 3). Mean thousand-kernel weight for Akaki surpassed the standard thousand-kernel weight (35- $40 \mathrm{~g}$ ) for pasta industry. At Akaki, Kilinto had superior thousand kernel weights followed by Ude and Yerer (Table 6). Like other quality traits, thousand-kernel weight was also location specific.

At Debre Zeit, the test weight decreased with increasing N level (Table 3). Yamazki and Briggle (1969) reported that grain shape is associated with packing efficiency while the environment where the crop is grown mostly affects kernel density [36]. Budak (2000) also confirmed that Kernel shriveling due to drought stress during grain filling period of wheat results in decreasing test weight and grain yield [37]. The prevailing weather

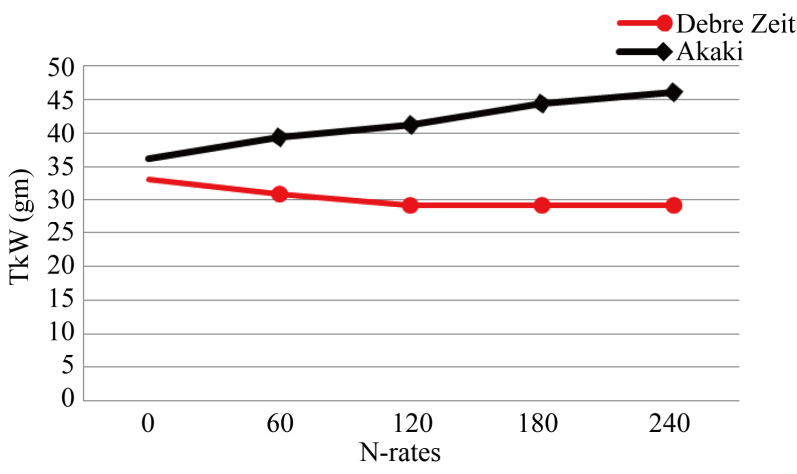

Figure 2. Relationships of thousand kernel weight to $\mathrm{N}$ rate at Debre Zeit and Akaki.

condition during grain filling period at Debre Zeit and Akaki corroborates this finding.

At Akaki, however, there was only significant difference among varieties (Table 5). Accordingly, Yerer provided higher test weight followed by Kilinto (Table 6). In contrast to Debre Zeit, slightly higher test weight was obtained at Akaki. In durum wheat, Troccoli and di Fonzo (1999) found a strong relationship between kernel size features and test weight [38].

At Debre Zeit, the two medium tall varieties were slightly affected by lodging. This could be attributed to residual soil $\mathrm{N}$, torrential rainfall, taller stem and windy condition. Stoskopf (1985) reported that lodging could be promoted by physical force exerted by wind, rain and/or by genetically weak straw [39]. Mean lodging at Debre Zeit was $11.6 \%$. Arsi-Robe was the tallest variety followed by Kilinto; the average lodging was higher on Arsi-Robe and Kilinto with $27.5 \%$ and $18.0 \%$, respectively, whereas, lodging is not a problem in Akaki.

\section{CONCLUSION}

The results of nitrogen fertilization effects on grain qualities of four released durum wheat varieties over two locations indicated that increase in the rate of applied nitrogen beyond $120 \mathrm{~kg} \cdot \mathrm{N} \cdot \mathrm{ha}^{-1}$ increased the vitreousness and wet gluten content over locations; and grain protein content, test weight and thousand-kernel weight of durum wheat at Akaki. However, quality grain was generally produced at Debre Zeit than at Akaki. Poor quality durum wheat production at Akaki may lead durum wheat farmers to shift their practices from durum to bread wheat. At this site, despite the rate of $\mathrm{N}$ fertilization, almost all varieties gave low quality produce in terms of vitreous kernel count and wet gluten content. In general, fertilizing at economic $\mathrm{N}$ rate based on site specific average yield potential and soil $\mathrm{NO}_{3}(\mathrm{~N})$ test is highly important to obtain economical yields and quality products. Additional application of $\mathrm{N}$ to soil in high precipitation areas like Akaki, however, boosts only the 
yield than the quality.

\section{ACKNOWLEDGEMENTS}

I am sincerely grateful to the technical assistance offered by G/Hiwot Abreha and Gizaw Wondimu of Debre Zeit Agricultural Research Center, and Yoseph Alemayehu of CIMMYT Ethiopia. Thanks are due to Dr. Geletu Bejiga of ICARDA-Ethiopia Office for the provision of financial support from ICARDA/USAID wheat seed project to realize publication of this article.

\section{REFERENCES}

[1] Abaye, A.O., Brann, D.E., Alley, M.M. and Griffey, C.A. (1997) Winter durum wheat: Do we have all the answers? Knowledge for the Common Wealth, Virginia State University, Publication No. 424-802.

[2] Pitz, W. (1992) Durum wheat/semolina/farina/pasta quality. North Dakota State University.

[3] D'Egidio, M.G. (2012) From seed to pasta in Ethiopia: Opportunities and challenges to overcome for smallholder farmers in Bale area. CRA Consiglio Perla Ricerca e la Sperimentazione in Agricolture, IAO.

[4] Gooding, M.J. and Devis, W.P. (1997) Wheat production and utilization. CAB International, Wallingford.

[5] Motozo, R., Fosi, S. and Giunta, F. (2004) Relationship between grain yield and quality of durum wheats from different eras of breeding. Euphytica, 140, 147-158. doi:10.1007/s10681-004-2034-5

[6] Franzen, D.W. and Goos, R.J. (1997) Fertilizing hard red spring wheat, durum, winter and rye. North Dakota State University Extension Service, SF-712.

[7] Tesemma, T. and Belay, G. (1991) Aspects of Ethiopian tetraploid wheats with emphasis on durum wheat genetics and breeding research. In: Gebre-Mariam, H., Tanner, D.G. and Hulluka, M., Eds., Wheat Research in Ethiopia: A Historical Perspective, IAR/CIMMYT, Addis Ababa, 47-71.

[8] Virman, S.M., Sahrawat, K.L. and Burford, J.R. (1982) Physical and chemical properties of vertisols and their management. 12th International Congress of Soil Science, 8-16 February 1982, New Delhi, 80-93.

[9] Sahrawat, K.L. (1980) Control of urea hydrolysis and nitrification in soil by chemicals-Prospects and problems. Plant and Soil, 57, 335-352. doi:10.1007/BF02211691

[10] Terman, G.L. (1979) Volatilization losses of nitrogen as ammonia from surface-applied fertilizers, organic amendments, and crop residues. Advances in Agronomy, 31, 189-223. doi:10.1016/S0065-2113(08)60140-6

[11] Impiglia, A. and Anderson, W. (1998) Essentials of a successful durum wheat crop. Agriculture Western Australia. http://www.agric.wa.gov.au

[12] Russell, R.S. (1977) Plant root systems: Their function and interaction with the soil. McGraw Hill Co., London, 277.

[13] Sigunga, D.O., Janssen, B.H. and Oenema, O. (2002) Denitrification risks in relation to fertilizer Nitrogen losses from vertisols and phaoezems. Communications in Soil Science and Plant Analysis, 33, 561-578. doi:10.1081/CSS-120002764

[14] Geleto, T., Tanner, D.G., Mamo, T. and Gebeyehu, G. (1996) Response of rainfed bread and durum wheat to source, level and timing of nitrogen fertilizer on two Ethiopian vertisols: II. N uptake, recovery and efficiency. Fertilizer Research, 44, 195-204. doi:10.1007/BF00750926

[15] Gashawbeza, B., Yaekob, A., Zemede, A., Kifetew, J. and Tadesse, T. (2003) Fertilizer N effects on yield and grain quality of durum wheat. Tropical Agriculture (Trinidad), 80, 146-151.

[16] Hadjichristoudoulou, A. (1979) Genetic and environmental effects of vitreousness of durum wheat. Euphytica, 28, 711-716. doi:10.1007/BF00038938

[17] Ethiopian Agricultural Research Organization (EARO) (2004) Directory of released crop varieties and their recommended cultural practices. EARO, Addis Ababa.

[18] Erokossa, T., Karl, S. and Thomas, G. (2006) Soil tillage and crop productivity on a vertisols in Ethiopian highlands. Soil Tillage Research, 85, 200-211. doi:10.1016/j.still.2005.01.009

[19] Chaney, K. (1990) Effects of nitrogen fertilizer rate on soil nitrate nitrogen content after harvesting winter wheat. Journal of Agricultural Science, Cambridge, 114, 171176.

[20] Campbell, C.A., Myers, R.J.K. and Curtin, D. (1995) Managing nitrogen for sustainable crop production. Fertilizer Research, 42, 277-296. doi:10.1007/BF00750521

[21] Nelson, D.W. and Sommers, L.E. (1982) Total carbon and organic matter. In: Page, A.L., et al., Eds., Methods of Soil Analysis Part 2: Chemical and Microbial Properties, 2nd Edition, Amer Society of Agronomy, Madison, 539579.

[22] Walkley, A. and Black, I.A. (1934) An examination of the Degtjareff method for determining soil organic matter and proposed modification of the chromic acid titration method. Soil Science, 37, 29-38. doi:10.1097/00010694-193401000-00003

[23] IITA (1979) Selected methods for soil and plant analysis. IITA (International Institute of Tropical Agriculture). Manual Series No. 1, Ibadan.

[24] Page, A.L., Miller, R.H. and Keeny, D.R. (1982) Methods of soil analysis II. Chemical and micro biological properties. No. 9 in the series of agronomy Inc. Soil Science Society of America, Inc., Madison.

[25] Yerima, B.P.K. (1993) Manual for good laboratory practice. Food and Agriculture Organization of the United Nation, Addis Ababa.

[26] Olsen, S.R., Cole, C.V., Wantanabe, F.S. and Dean, L.A. (1954) Estimation of available phosphorus in soils by extraction with sodium bicarbonate. Circular (US Department of Agriculture), 939, $19 \mathrm{p}$.

[27] Houba, V.J.G., Vander Lee, J.J., Novozamsky, I. and Waligna, I. (1989) Soil and plant analysis a series of syllabi. Part 5: Soil analysis procedures. Wageningen Agricultural University, Wageningen, The Netherlands. 
[28] Caldicott, J.J.B. and Nuttal, A.M. (1979) A method for the assessment of lodging in cereals crops. Journal of the National Institute of Agricultural Botany, 15, 88-91.

[29] International Association for Cereal Science and Technology (ICC) (2000) Standard methods of international association for cereal science and technology. ICC, Vienna.

[30] SAS Institute (2000) SAS/STAT user's guide: Version 7. SAS Institute Inc., Cary.

[31] Ames, N.P., Clarke, J.M., Dexter, J.E., Woods, S.M., Selles, F. and Marchylo, B. (2003) Effects of nitrogen fertilizer on protein quantity and gluten strength parameters in durum wheat (Triticum turgidum L. var. durum) cultivars of variable Gluten strength. Cereal Chemistry, 80, 203-211. doi:10.1094/CCHEM.2003.80.2.203

[32] Metho, A.L., Hammes, P.S. and De Beer, J.M. (1997) Effect of cultivars and soil fertility on grain yield, yield components and grain nitrogen content of wheat. African Crop Science Journal, 3, 695-709.

[33] Simmonds, D.H. (1989) Inherent quality factors in wheat. Wheat and Wheat Quality in Australia, CSIRO, 31-61.
[34] Srivastava, J.P. (1984) Durum wheat-its world status and potential in the Middle East and North Africa. Rachis (Barley and Wheat Newsletter), 3, 1-8.

[35] Campbell, C.A., Davidson, H.R. and Warder, F.G. (1977) Effects of fertilizer $\mathrm{N}$ and soil moisture on yield, yield components, protein content and $\mathrm{N}$ accumulation in the above ground parts of spring wheat. Canadian Journal of Soil Science, 57, 311-327. doi:10.4141/cjss77-036

[36] Yamazaki, W.T. and Briggle, L.W. (1969) Components of test weight in soft wheats. Crop Science, 9, 457-460. doi:10.2135/cropsci1969.0011183X000900040021x

[37] Budak, N. (2000) Heritability, correlation and genotype $x$ year interactions of grain yield, test weight and protein content in durum wheats. Turkish Journal of Field Crops, $5,35-40$

[38] Troccoli, A. and di Fonzo, N. (1999) Relationship between kernel size features and test weight in Triticum durum. Cereal Chemistry, 76, 45-49. doi:10.1094/CCHEM.1999.76.1.45

[39] Stoskopf, N.C. (1985) Cereal grain crops. Reston Publishing Company, Inc., Reston. 